Journal of Labor Economics, 16, forthcoming, 1998.

\title{
The Use of Replacement Workers in Union Contract Negotiations: The U.S. Experience, 1980-1989
}

\author{
Peter C. Cramton and Joseph S. Tracy*
}

\begin{abstract}
It is argued in many circles that a structural change occurred in U.S. collective bargaining in the 1980s. Strike incidence declined, dispute incidence increased, and the composition of disputes shifted away from strikes and toward holdouts. We investigate the extent to which the hiring of replacement workers can account for these changes. For a sample of over 300 major strikes since 1980, we estimate the likelihood of replacements being hired. We find that the risk of replacement is lower for bargaining units with more experienced workers, and declines during tight labor markets. The composition of disputes shifts away from strikes as the predicted risk of replacement increases. In addition, the overall level of disputes increases as a result of the shift in the composition of disputes. Based on our estimates reducing the predicted replacement risk faced by bargaining units to the pre-1982 levels would have lead to a reduction in the dispute incidence by around 5 percentage points, an increase in the fraction of disputes involving a strike by around 4 percentage points, and an increase in the strike incidence by around 0.8 percentage points.
\end{abstract}

"University of Maryland and Federal Reserve Bank of New York. Funding has been provided by the National Science Foundation. We thank the Bureau of National Affairs for providing us with wage and strike information. We thank workshop participants at the City University of New York, U.S. Department of Justice, University of North Carolina, University of Maryland, University of Pittsburgh, and U.S. Census Bureau for their helpful comments. The views expressed in the paper are those of the authors and are not necessarily reflective of views at the Federal Reserve Bank of New York or the Federal Reserve System. 
It is widely believed that U.S. collective bargaining has changed substantially in the 1980s from earlier decades. ${ }^{1}$ One piece of evidence used to support this view is that strike activity as measured by the Bureau of Labor Statistics (BLS) declined by over 50\% from its level in the 1970s. Less well known is that the overall level of labor disputes increased in the 1980s. The decline in strike incidence was the result of a shift in the composition of labor disputes. Cramton and Tracy (1992) demonstrate that a sharp increase occurred in the percentage of labor disputes that are settled without a strike under an extension of the expired contract (a "holdout").

The reason(s) for the increase in overall disputes and the shift in the composition of disputes has yet to be empirically established. Labor leaders argue that a change in collective bargaining tactics has been necessitated by the increased tendency for firms to hire replacement workers if the union calls a strike. Organized labor has lobbied for several years for Congress to "restore the strike threat" by amending the labor law to ban the use of permanent replacements. ${ }^{2}$ Careful consideration of such legislation is hampered by the lack of any comprehensive analysis of the use of replacement workers in the U.S..

In this paper, we begin to answer the question of whether the changes in collective bargaining outcomes in the 1980s can be explained by the use of replacement workers. We analyze the most comprehensive data collected to date on the use of replacement workers in U.S. union contract negotiations for the 1980s. We present a detailed description of the determinants of the firm's decision to hire replacement workers during a strike. We show that the replacement risk facing a union varies systematically with the work experience of its members and the tightness of the local labor market. We use this systematic variation in replacement risk to measure its impact on the union's threat choice between strike and holdout. We find that increases in the predicted replacement risk significantly increases the likelihood that the union selects the holdout threat; that the induced reduction in the likelihood of a strike given a dispute increases the probability of a dispute; and that the net impact is a small reduction in the overall strike incidence. Our best estimate is that increased use of replacements can explain about half of the unaccounted for shifts in bargaining outcomes in the 1980s.

The outline of the paper is as follows. In section 1 we summarize our earlier efforts at establishing that the shift in collective bargaining patterns represents a change in the process of bargaining. In section 2 we summarize the existing empirical literature on replacement workers. In section 3 we discuss our data collection efforts and present an overview of the use of replacement workers in the 1980s. In section 4 we

\footnotetext{
${ }^{1}$ See Cappelli (1982), Freedman (1982, 1985), and Mitchell (1982, 1983) for related discussions.

${ }^{2}$ The first bill was introduced into Congress in 1988 by Representative Brennan which proposed banning the use of permanent replacements during the initial ten weeks of a strike. A strengthened version of this bill was introduced into the 101 st Congress (H.R. 3936 \& S. 2112) which proposed completely banning the use of permanent replacements. In 1992, similar legislation passed in the House but failed in the Senate. In 1993, the replacement bill was reintroduced (H.R. 5 \& S. 55). On 8 March 1995, President Clinton signed an executive order banning the federal government from doing business with firms that use permanent replacements.
} 
present a simple model of the firm's decision to use replacements. Our empirical implementation of this model is given in section 5 . We evaluate the economic significance of our findings, and compare them to estimated replacements effects from Canadian data. The paper ends with a summary of our findings.

\section{A Perspective on Collective Bargaining in the 1980s}

The 1980s proved to be a difficult decade for the U.S. labor movement. The private sector unionization rate fell into single digits leaving many to wonder if unions would soon become an anachronism. In the U.S., unions like politicians are typically measured by the general populace in terms of their impact on the pocketbook. The changing economic and political landscape in the 1980s may have seriously imperiled the ability of unions to produce visible benefits for their members. ${ }^{3}$

Many of the benefits of unionization are embodied in the labor contracts they negotiate. The process of labor contract negotiations, then, is vital to the institutional interests of unions. An examination of the collective bargaining process in the 1980s reveals significant changes from the 1970s. Cramton and

Tracy (1992) emphasize that unions have multiple threat options available when a labor contract expires. The union can either call a strike or extend the former contract, a holdout. In a holdout, the union applies pressure on the firm through a work-to-rule, slow-down, or other "in-plant" strategies. Holdouts need not involve the large costs common to strikes. Indeed, the theory applies regardless of the extent of holdout costs (and is largely invariant to the size of these costs). The cost may simply be from maintaining the possibility of a strike, rather than from more aggressive in-plant strategies by the union. Figure 1 illustrates that the incidence of strikes fell in the 1980s while the incidence of holdouts rose sharply, resulting in an increase in the overall dispute incidence.

Holdouts are defined as in Cramton and Tracy (1992) to be any contract signed without a strike more than one day after the prior contract expiration. Dispute incidence is defined as the sum of the strike and holdout incidence. Our choice of this definition of a holdout is motivated by the strong deadline effect which is exhibited in the data. The empirical hazard rate into settlement is quite high on the expiration date of the previous contract as well as the following day. The settlement rate declines significantly between the first and second day following the prior expiration date, and remains roughly flat over the next month. Nonetheless, it is surely the case that some holdouts are misclassified using our procedure. For example, it may be that a settlement is reached at the contract expiration, but that it is not ratified until several days after expiration. Alternatively, some settlements may involve periods of costly holdout before contract expiration, and hence are better classified as holdouts. Unfortunately, data on the size and timing of bargaining costs does not exist.

\footnotetext{
${ }^{3}$ See Farber and Krueger (1992) for an analysis of changing worker attitudes toward unions. Another indication of this weakness is the recent merger activity between the United Rubber Workers and the United Steel Workers, and between the United Auto Workers, the United Steel Workers and the International Association of Machinists.
} 
We simply do the best we can with the best data that is available. The upward trend in holdouts in the 1980s, though, is robust to defining a holdout using a 7-day window and a 30-day window between the prior expiration date and the beginning of the holdout. If classification errors are more likely with short duration holdouts, then the trend is unlikely to be due to increased classification problems in the 1980s.

An explanation for this increase in dispute incidence and shift in the composition of labor disputes has not been demonstrated to date. Labor leaders emphasize the growing risk of union workers being replaced in the event of a strike. ${ }^{4}$ In August 1981, President Reagan replaced the air traffic controllers after their union, PATCO, called an illegal strike. As a result of the President's action, the union was decertified. ${ }^{5}$ Unions claim that this dramatic action signaled to the private sector that hiring replacements is both legal and acceptable. The Industrial Union Department of the AFL-CIO in a 1986 manual for its union leaders titled The Inside Game: Winning With Workplace Strategies argues that the threat of replacement has significantly diminished the attractiveness of the strike threat relative to the holdout threat:

To be sure, the strike in many cases is still a powerful and effective weapon. But when an employer begins trying to play by the "new rules" and actually force a strike, staying on the job and working from the inside may be more appropriate (page 5, emphasis in original).

Whether the 1980s represent a structural break in the process of collective bargaining is addressed in Cramton and Tracy (1994). We estimate the first empirical model of the determinants of labor disputes, and the composition of these disputes between strikes and holdouts. The observed changes in the patterns of strike and holdout incidence illustrated in Figure 1 could be the result of changes in the economic environment, rather than of changes in the collective bargaining process itself. Using data on twelve hundred major contracts negotiated between 1970 and 1989, we find mixed evidence supporting the structural change hypothesis.

Without controlling for any covariates, dispute incidence in the post-PATCO period is only 2.3 percentage points higher than in the earlier period, an insignificant difference. Once we control for changes in the underlying covariates, the difference increases to 7.5 percentage points and is significant. If we replace the post-PATCO indicator with individual year effects for 1982-1989, we find that the year effects are jointly significant, although only 1986 is individually significant. The point estimate indicates that the actual dispute incidence was 27 percentage points higher than predicted in 1986.

\footnotetext{
${ }^{4}$ The right of firms to hire replacement workers during an economic strike was upheld by the Supreme Court in its 1938 decision Mackay Radio \& Telegraph Co. v. NLRB (304 U.S. 333). Once the strike is settled, the firm must restrict its future hiring from within the bargaining unit.

${ }^{5}$ On 12 August 1993, President Clinton lifted the ban on hiring former PATCO members that had participated in the strike.
} 
Similarly, without controlling for any covariates the fraction of disputes involving a strike is 13 percentage points lower in the post-1981 period, a significant difference. When we control for the covariates suggested by our bargaining model (Cramton and Tracy 1992), this difference falls to 7.5 percentage points and is only marginally significant. Replacing the post-1981 indicator with eight year indicators, we find that the year effects are jointly insignificant and that 1989 is the only individually significant year effect.

To test for the stability of our estimated bargaining model over the two decade period, we interact the post-1981 indicator with each variable in our empirical model. The chi-square statistic (probability value) for the joint significance of the intercept and slope interactions is 26.1 (0.02), and for the slope interactions alone is 23.4 (0.02). The interactions with the industry employment residual and the real wage change over the prior contract were both individually significant. In contrast to the evidence regarding a shift in the overall composition of disputes, there is clearer evidence that the responsiveness of the union's threat choice to underlying economic variables has shifted since 1981.

The key interaction from the viewpoint of the theory is with the real wage change over the prior contract. Our bargaining model predicts that the attractiveness of the strike threat decreases as the real wage at the end of the prior contract increases. This suggests a negative coefficient on the real wage change over the prior contract in predicting the likelihood of a strike given a labor dispute. The data indicate an increase in the marginal effect associated with the real wage change of 13 percentage points between the pre- and the post1981 period, a statistically significant change. This increase is sufficient to reverse a negative and significant coefficient on the real wage change for the $1970-81$ period to a positive and marginally significant coefficient for the 1982-89 period.

\section{Summary of Replacement Worker Literature}

There are only a handful of papers that analyze data on the use of replacement workers in U.S. contract negotiations. This reflects the difficulty in obtaining replacement data. The General Accounting Office (GAO 1991) undertook a study of the use of replacements at the request of the Senate Subcommittee on Labor which was considering replacement legislation. The GAO obtained data from the Federal Mediation and Conciliation Service (FMCS) on all strikes in 1985 and 1989. ${ }^{6}$ They surveyed the firm and union involved in all major strikes (those involving at least 1,000 workers) and a random sample of the smaller strikes. From this data, the GAO reports that $11 \%$ (17\%) of major (smaller) strikes in 1985 involved replacements, and 9\% (16\%) involved replacements in 1989. The GAO also reports that the occurrence of replacements was three times higher in strikes which lasted at least a month in duration.

\footnotetext{
${ }^{6}$ Only bargaining units covered by the National Labor Relations Act (NLRA) are required to file with the FMCS before a strike. As a result, the GAO sample excludes negotiations in the trucking and airline industries, which are covered by the Railway Labor Act.
} 
Olson (1991) reports on the use of replacements in major U.S. strikes between 1984-1988, and in New York strikes for three periods before the NLRA. For the 1980s, Olson finds that the incidence of replacements is $10.5 \%$. For the earlier periods, Olson finds that the use of replacements ranged from a low of $1.5 \%$ in 192631 to a high of $61 \%$ in 1881-86. Like the GAO report, Olson also finds that the use of replacements is associated with longer strike durations. Interpreting this correlation is difficult, however, without information on the timing of the hiring of the replacements. The finding is consistent with the hazard rate from strike to settlement being higher, lower, or unchanged following the hiring of replacements.

Based on a sample of thirty-five large strikes in the U.S. and twenty-one small strikes in New York from 1984 to 1988, Gramm (1991) reconfirms that strike durations are much longer when permanent replacements are hired. Gramm reports that permanent replacements were hired in $20 \%$ of her strikes and temporary replacements in $8 \%$. Gramm's data also includes information on the firm's operating capacity during the strike. In the U.S. sample, the mean operating capacity was $57 \%$ with no replacements, $90 \%$ with temporary replacements, and $77 \%$ with permanent replacements. In the New York sample, the mean operating capacity was around $60 \%$ regardless of the use of replacements.

Schnell and Gramm (1994) and Gramm and Schnell (1994) extend Gramm's earlier work. Schnell and Gramm (1994) examine the GAO replacement data. They classify strikes into three categories: no intent to hire permanent replacements was given and no permanent replacements were hired (64.5\% of the sample), intent to hire permanent replacements was given but no permanent replacements were hired ( $15.5 \%$ of the sample), and intent to hire permanent replacements was given and permanent replacements were hired (19.9\% of the sample). They estimate a Cox proportional hazard model of strike durations controlling for the bargaining unit size, establishment size, state unemployment rate, an indicator for whether the observation came from the 1985 sample, an indicator for replacement intent given but no replacements hired, and an indicator for replacement intent given and replacements hired. Both replacement indicators are negative and significant in the overall sample. Unfortunately, Schnell and Gramm can not control for the timing of the announcement of the intent to hire permanent replacements nor the decision to hire permanent replacements. Gramm and Schnell (1994) find that firms hiring permanent replacement workers have a higher operating capacity even after controlling for other factors which may affect the firm's operating effectiveness. The percentage of strikers who are reinstated following the settlement of a strike is significantly lower for strikes involving permanent replacements. Finally, they report that firms hiring permanent replacements conclude the negotiations on average with more favorable terms. ${ }^{7}$

\footnotetext{
${ }^{7}$ This finding is sensitive to how the authors treat not reaching a contract. The positive effect of hiring replacements occurs when not reaching a contract is treated as the most favorable outcome to the firm. When the authors delete the negotiations that fail to reach a contract, then permanent replacements yield on average less favorable terms to the firm.
} 


\section{Collection of Replacement Data}

We have carried out an extensive project to collect data on the use of replacement workers during contract negotiations in the 1980s. We restricted our collection efforts to strikes involving bargaining units with at least 1,000 workers. In principal, these major strikes can be matched up with collective bargaining chronologies compiled by the BLS that we have analyzed in our earlier studies.

Using previously collected strike information, we conducted computer literature searches for each strike in our sample using the Lexis/Nexis service. ${ }^{8}$ This service provides the full text of most major newspapers, magazines and trade journals since the early 1980s. Each strike in our sample generated typically more than two dozen articles, and those that involved replacements generated far more media attention. Information on the use of replacements and indications of violence were recorded for each strike in our sample. ${ }^{9}$

We have data on 3,129 contract negotiations involving 312 strikes in the 1980s that can be linked to the BLS bargaining chronologies. The dispute incidence in this sample is $58.9 \%$, the strike incidence $10.0 \%$, and the fraction of strikes involving replacements $14.1 \%$. The incidence of permanent replacements given a strike is $6.7 \%$, while the incidence of temporary replacements given a strike is $7.4 \%$. Table 1 illustrates that the likelihood of replacements being hired during a strike varies across years. While there is considerable variation in these figures due to the small number of major strikes in a given year, this variation suggests that the decision to use replacements may depend on underlying macro and labor market conditions. Table 2 illustrates that risk of replacement also varies across industry classifications. Again, the impression is that the decision to use replacements may depend on product market conditions and characteristics of workers in each industry. Together, these two tables suggest that the risk of replacement is unlikely to be uniform across bargaining units and time periods, but rather may follow systematic patterns. Identifying these patterns will point to negotiations in the 1980s where the replacement risk remained low, and consequently strikes should have remained a viable union threat choice.

Our data allow us to paint a general picture of the bargaining environment where replacements are hired. Wages are the primary issue in roughly $64 \%$ of the major strikes in the 1980 s. The onset of concession bargaining is evidenced by the fact that $14 \%$ of strikes where wages were the primary issue involved demands by the firm for nominal wage reductions. Importantly, though, strikes where replacements were hired account

\footnotetext{
${ }^{8}$ The strike information is gathered from BLS and Bureau of National Affairs (BNA) reports. This data is available through ICPSR by referencing Cramton and Tracy (1992).

${ }^{9}$ As a check on the accuracy of our combined BLS, BNA, Lexis/Nexis strike information, we surveyed each of the firms and unions involved in these strikes. We first developed a contact data base listing the appropriate firm and union representatives, addresses, and phone numbers. This information was verified through phone contacts. The survey requested corrections and/or additions to our strike/replacement information. While the response rate was only $15 \%$, the returned surveys confirmed the accuracy of our information.
} 
for $32 \%$ of these wage reduction cases, more than twice the share of replacements in overall strikes. Further, the use of permanent replacements is often preceded by layoffs during the prior contract. Roughly one-third of strikes involve violence during the negotiations, though the incidence of violence increases when replacements are hired. Forty-six percent of negotiations involving major violence were associated with the use or replacements. When replacements are hired, on average 36\% (permanent) and $41 \%$ (temporary) of the bargaining unit is replaced. The firm's operating capacity during a strike is higher on average when the firm hires replacements. The mean operating capacity figures in our sample are $43 \%$ when no replacements are hired, $67 \%$ when temporary replacements are hired, and 56\% when permanent replacements are hired.

Earlier studies consistently find longer strike durations associated with the hiring of replacements. Not surprisingly, our data illustrate the same association. The mean strike duration in our sample is 32 days if no replacements are hired, 70 days if temporary replacements are hired, and 217 days if permanent replacements are hired. A further understanding of this effect requires information on the timing of the onset of hiring of replacements. The mean number of days between the prior contract expiration and the hiring of replacements in our data is 12 days for temporary replacements and 48 days for permanent replacements. Comparing these figures suggests that the impact of replacements is to reduce the hazard rate from strike to settlement. However, one must be careful in interpreting this finding, since many of the longest "strikes" are actually situations where the union workforce has been replaced and the contract negotiations have effectively ceased. ${ }^{10}$

\section{Incorporating Fixed Costs and Replacements Into a Bargaining Model}

In this section, we provide a brief sketch of how the replacement decision can be added to the basic wage bargaining model in Cramton and Tracy (1992). Our purpose is to show how the threat of replacement affects the union's decision to strike. We find that as the risk of replacement increases the strike threat becomes less attractive to the union. Strike incidence, then, should drop with a greater risk of replacement. This shift away from the relatively expensive threat leads to a higher level of total disputes. Readers not interested in this extension should skip to the next section.

We begin by extending our earlier model to include fixed costs of initiating a dispute. This extension serves two purposes. First, by including a fixed cost of striking (in addition to the constant variable cost), the model is able to explain why overall dispute incidence may increase as strike incidence falls, which is a prominent feature of the data shown in Figure 1. Second, the model with fixed costs is a building block for the replacement model, since the replacement decision involves fixed costs, namely, the cost of hiring and training replacement workers.

\footnotetext{
${ }^{10}$ Firms hiring permanent replacements have an incentive to prolong a strike. Replaced striking workers retain their voting rights for a period of twelve months following the start of the strike (Landrum Griffin amendments to the NLRA, 1959).
} 
The union and firm are bargaining over the wage $w$ to be paid during a contract of length $\mathrm{T}$. The union is uncertain about the firm's willingness to pay $v$. Bargaining begins with the union selecting a threat $\theta \in\{H, S\}$, either holdout or strike, which applies until a settlement is reached. In the holdout threat, the union workers put pressure on the firm while continuing to work under the terms of the expired contract. In the strike threat, the union workers withhold their labor services. There is some inefficiency associated with disagreement in either threat.

Inefficiencies arise in the holdout threat through union tactics such as work-to-rule and sickouts. In the threat $\theta$, the payoff to the union is $x_{\theta}$ and the payoff to the firm is $a_{\theta} v-b_{\theta}$, where $a_{\theta} \in[0,1)$ and $b_{\theta} \geq 0$. For the holdout threat $x_{H}=w_{0}$ and $b_{H}=w_{0}$, where $w_{0}$ is the wage under the expired contract. The term $1-a_{\theta}$, which we call the dispute cost, measures how far the parties are from the Pareto frontier during the threat $\theta$. Since the total payoff in agreement is $v$ and the total payoff in the threat is $a_{\theta} v-b_{\theta}+x_{\theta}$, the inefficiency during disagreement is $\left(1-a_{\theta}\right) v+b_{\theta}-x_{\theta}=\left(1-a_{\theta}\right)\left(v+c_{\theta}\right)$, where $c_{\theta}=\left(b_{\theta}-x_{\theta}\right) /\left(1-a_{\theta}\right)$. For the holdout threat, $c_{H}=0$ so the inefficiency during disagreement simplifies to $\left(1-a_{H}\right) v$. This inefficiency is the pie that can be gained through settlement.

Moreover, assume that there are fixed costs of initiating a dispute. Let $k_{\mathrm{f} \theta}$ and $k_{\mathrm{u} \theta}$ be the fixed costs for the firm and union if the threat $\theta$ is initiated, and $k_{\theta}=k_{\mathrm{f} \theta}+k_{\mathrm{u} \theta}$ be the joint fixed cost. To make the fixed costs easily comparable to the flow payoffs (e.g., $v$ and $w$ ), each $k$ should be thought of as the flow $k$ from $[0, T]$ that is equivalent to the one-time fixed cost $K$; that is, $k=r K /\left(1-\mathrm{e}^{-r T}\right)$. The fixed costs may be from a loss of goodwill in the employment relationship, or costs of shifting production or looking for temporary employment. In addition, immediate settlement avoids the fixed cost $k_{\theta}$.

An outcome of the bargaining, denoted $\langle t, w, \theta\rangle$, specifies the time of agreement $t$, the contract wage $w$ at the time of agreement, and the threat $\theta \in\{H, S\}$ before agreement. We assume that the union and firm are risk neutral and that the payoff flows, both during the threat and after agreement, are constant over time. The overall payoffs, then, are calculated as a combination of the threat payoff and the agreement payoff, weighted by the fraction of time spent in each outcome.

After the union's threat choice, the union and firm alternate wage offers, with the union making the initial offer. The side receiving an offer has two possible responses: (1) a counteroffer, in which case the bargaining continues, or (2) acceptance, in which case the bargaining ends with labor supplied at the offered wage for the remainder of the contracting period. The fixed costs $k_{\theta}$ provide an added incentive to accept the union's initial offer, since only immediate acceptance avoids incurring the fixed costs. As in Admati and Perry (1987), a bargainer can delay responding to an offer. This assumption leads to the signaling equilibrium in which the firm signals its value through its willingness to delay agreement. For simplicity, we assume that the minimum time between offers is arbitrarily small. 
The equilibrium takes a simple form. If the wage $w_{0}$ under the expired contract is sufficiently low (below an indifference level $\tilde{\mathrm{w}})$ the union selects the strike threat; otherwise $\left(w_{0} \geq \tilde{\mathrm{w}}\right)$ the union selects the holdout threat. The indifference level $\tilde{\mathrm{w}}$ depends on the threat payoffs and the distribution of $v$. A second indifference level $m$ is determined by the union's initial offer. The firm accepts the union's initial offer if its valuation $v$ is above $m$ and otherwise rejects the offer. If the firm rejects the offer, it waits until it has credibly signaled its valuation before making an acceptable counteroffer. The counteroffer is the full-information wage offer, which in the case of equal discount rates is given by $w_{\theta}(v)=x_{\theta}+1 / 2\left(1-a_{\theta}\right)\left(v+c_{\theta}\right)$. The union gets its threat payoff, $x_{\theta}$, plus one-half of the inefficiency avoided by settlement, $\left(1-a_{\theta}\right)\left(v+c_{\theta}\right)$. The counteroffer is independent of the fixed costs, since at the time of the offer the fixed costs are already sunk. The fixed costs, however, affect both the union's initial offer and the firm's decision to accept.

Proposition 1. Let $\theta=\left(x_{\theta}, y_{\theta}\right)$ be the threat chosen by the union, where $y_{\theta}=a_{\theta} v-b_{\theta}$ and $c_{\theta}=\left(b_{\theta}-x_{\theta}\right) /\left(1-a_{\theta}\right)$. In the limit as the time between offers goes to zero, there is a perfect Bayesian equilibrium with the following form:

$$
k_{f \theta}-k_{\theta} F(m)+\frac{1}{2}\left(1-a_{\theta}\right)\left[\left(m+c_{\theta}\right)(1-F(m))+\int_{\ell}^{m} \frac{\left(v+c_{\theta}\right)^{2}}{m+c_{\theta}} d F(v)\right] .
$$

- The union makes an immediate offer of $k_{f \theta}+w_{\theta}(m)$, where $w_{\theta}(m)=x_{\theta}+1 / 2\left(1-a_{\theta}\right)\left(m+c_{\theta}\right)$ and $m \in[1, h)$ maximizes

- The firm accepts the offer if $v \geq m$. Otherwise, if $v<m$, the firm waits until $(m-v) /\left(m+c_{\theta}\right)$ of the contract period has passed before offering $w_{\theta}(v)=x_{\theta}+1 / 2\left(1-a_{\theta}\right)\left(v+c_{\theta}\right)$, which is accepted immediately by the union.

$$
\begin{gathered}
U_{\theta}=k_{f \theta}-k_{\theta}\left[F(m)+\left(m+c_{\theta}\right) f(m)\right]+x_{\theta}+\left(1-a_{\theta}\right)\left(m+c_{\theta}\right)(1-F(m)) \\
V_{\theta}=-k_{f \theta}-k_{\theta}\left(m+c_{\theta}\right) f(m)+a_{\theta} E(v)-b_{\theta}+\left(1-a_{\theta}\right) \int_{m}^{h}\left(v+c_{\theta}\right) d F(v) \\
L_{\theta}=k_{\theta} F(m)+2 k_{\theta}\left(m+c_{\theta}\right) f(m)+\left(1-a_{\theta}\right)\left[c_{\theta}-\left(m+2 c_{\theta}\right)(1-F(m))+\int_{\ell}^{m} v d F(v)\right] .
\end{gathered}
$$

- If $m>1$, the union's expected payoff from the threat $\theta$ is $U_{\theta}$, the firm's expected payoff is $V_{\theta}$, and the expected loss is $L_{\theta}$, where 
- If $m=1$, then the union makes the initial offer $k_{f \theta}+w_{\theta}(1)$, which is surely accepted by the firm.

$U_{\theta}=k_{f \theta}+w_{\theta}(1), V_{\theta}=-k_{f \theta}+E(v)-w_{\theta}(1)$, and $L_{\theta}=0$.

Proof: This is a straight-forward extension of Proposition 1 in Cramton and Tracy (1992), so we do not provide details. Since $k_{\theta}$ is a fixed cost, it does not affect the bargaining once the cost is incurred. In particular, the firm's response to the union's initial offer is as in Cramton and Tracy (1992). It does, however, change the incentive to initiate a dispute. Firm $m$ must be indifferent between accepting the initial offer or immediately countering with $w_{\theta}(m)$, which is accepted by the union. Hence, the union's initial offer $w$ is accepted by the firm if $v \geq m$ provided $m-w=m-w_{\theta}(m)-k_{f \theta}$, or $w=k_{f \theta}+w_{\theta}(m)$. Given this acceptance rule, the union selects $m$ (or equivalently $w$ ) to maximize its expected payoff $U(m)$, which is equation (M). Taking the derivative with

$$
-k_{\theta} f(m)+\frac{1}{2}\left(1-a_{\theta}\right)\left[1-F(m)-\int^{m}\left(\frac{v+c_{\theta}}{m+c_{\theta}}\right)^{2} d F(v)\right]=0
$$

respect to $m$ yields the first-order condition

If $k_{\theta}<1 / 2\left(1-a_{\theta}\right) / f(1)$, then $U^{\prime}(1)>0$ and an interior maximum satisfying the first-order condition is guaranteed $\left(U^{\prime}(h)<0\right.$ and $U(\cdot)$ is continuous in $\left.m\right)$. Hence, we can substitute the first-order condition into the formula for $U(m)$ to yield $U_{\theta}$. The firm's expected payoff and the expected loss are calculated similarly. If $m=1$, the union makes an offer that is surely accepted.

Consistent with the joint cost hypothesis (Kennan 1980, and Reder and Neumann 1980), it is only the joint fixed cost $k_{\theta}$ that affects the probability of a dispute in the threat $\theta$. As the joint fixed cost increases, the union makes an offer that is accepted with higher probability. Even a small fixed cost can have a large effect on the probability of a dispute in the threat $\theta$. In the benchmark model from Cramton and Tracy (1994) (with parameters set to fit the data), introducing a joint fixed cost of striking equal to $1 \%$ of the expected pie reduces the probability of a strike in the strike threat from $52 \%$ to $22 \%$. Strike incidence drops to zero when the joint fixed cost is increased to $1.8 \%$ of the expected pie.

A modest fixed cost of striking can mean that the probability of a strike under the strike threat is much less than the probability of a holdout under the holdout threat (assuming no fixed costs associated with the holdout threat). In this case, a shift in disputes away from striking (for example, a drop in $w_{0}$ ) reduces strike incidence, but may increase holdout incidence by much more resulting in an increase in the dispute incidence, as occurred in the 1980s.

The fixed cost $k_{\theta}$ also affects the union's threat decision. The union selects the strike threat if $U_{S}>U_{H}$. Recall that for the holdout threat $x_{H}=w_{0}$ and $c_{H}=0$. Substituting, the union selects the strike threat if $w_{0}<\tilde{w}$, where $\tilde{w}=U_{S}-\left(1-a_{H}\right) m_{H}\left(1-F\left(m_{H}\right)\right)$. From Proposition 1 , we see that $U_{S}$ depends on $k_{f S}$ and $k_{u s}$. As the union's 
fixed cost of striking increases, $U_{S}$ falls, implying a shift toward holdouts. An increase in the firm's fixed cost, typically increases $U_{S}$, implying a shift toward strikes.

Strike incidence (what we observe in the data) depends on the combined effect of the change in the probability of a dispute given that the strike threat is selected and the shift in the probability that the union selects the strike threat. Table 3 shows how introducing a 1\% fixed cost of striking affects strike incidence and holdout incidence in the benchmark model. Regardless of who bears the fixed cost, strike incidence drops substantially, because of the large drop in the probability of a dispute given that the strike threat is selected. The drop is largest when the union bears the fixed cost, since in this case the strike threat becomes less attractive and is adopted less often.

We further modify this game by now allowing the firm to decide to replace the workforce. Replacement can be thought of as a new threat $\theta=R$ with its own threat payoffs. If the union selects the strike threat and the firm finds the union's initial offer unacceptable, then the firm decides whether to hire temporary replacements at a fixed cost $k_{f R}$. The cost $k_{f R}$ represents the hiring and training costs associated with replacement. It is assumed that the replacements' productivity is some fraction $a_{R}<1$ of the productivity of the prior workers. ${ }^{11}$

To understand the implications of this extension of the model, first consider the case where $v$ and $k_{f R}$ are known by the firm and the union. The full-information settlement wages under the three threats, $w_{H}(v), w_{S}(v)$, and $w_{R}(v)$, play an essential role in determining the outcome. If the cost of replacement is prohibitively high or the replacement wage is higher than the strike wage, $w_{R}(v) \geq w_{S}(v)$, then the firm never hires replacements. The settlement wage in this case is the strike wage $w_{S}(v)$ or the holdout wage $w_{H}(v)$, whichever is greater.

Now suppose that the replacement wage is less than the strike wage, $w_{R}(v)<w_{S}(v)$. This wage differential gives the firm an incentive to replace if the cost of replacement is not too high. In the event that $w_{S}(v)$ $w_{R}(v)>k_{f R}$ and that the union selects the strike threat, it will reduce its wage demand in order to keep the firm from hiring replacements. The union offers the wage $w=k_{f R}+w_{R}(v) \leq w_{S}(v)$, such that the firm is indifferent between accepting $w$ or replacing the workforce and settling at $w_{R}(v)$. As a result, we never observe replacements used, but the threat of replacement reduces the union's wage demand in the strike threat.

Now suppose that $v$ is again common knowledge, but the firm has private information about the cost $k_{f R}$ of replacement. In particular, suppose the cost of replacement is either low or high, $k_{f R} \in\{L, H\}$, and let $p=\operatorname{Pr}\left(k_{f R}=L\right)$ be the probability of a low replacement cost. Assume that $w_{S}(v)-w_{R}(v) \geq H$, so that the union must be concerned about replacement by both types of firms. There are two possible equilibria, pooling and separating.

\footnotetext{
${ }^{11}$ The replacements are temporary in that they are employed by the firm only until a settlement is reached with the union. In addition, we assume that the firm's decision to use replacements does not affect $v$ once a settlement with the union is reached.
} 
Pooling equilibrium. If $L$ and $H$ are close, the union will make a pooling offer that both firm types accept: the union offers the wage $w_{L}=L+w_{R}(v)$ that makes the low-cost firm indifferent between accepting and replacing (the high-cost firm strictly prefers to accept). The union successfully avoids replacement by offering a sufficiently low wage. The strike threat, though, is made less attractive by the firm's option to replace since the union must reduce its strike demand to avoid replacement.

Separating equilibrium. As the gap between $L$ and $H$ widens, it becomes increasingly costly for the union to prevent the low-cost firm from replacing. At some point, the equilibrium switches from the pooling equilibrium (without replacement) to a separating equilibrium in which the union offers the wage $w_{H}=H+w_{\mathrm{R}}(v)$ that makes the high-cost firm indifferent between accepting and replacing. The low-cost firm strictly prefers to replace in this case. In this equilibrium, the probability of replacement is just $p$ and the union reduces its offer $w_{H}$ to keep the high-cost firm from replacing. The expected wage is $p w_{R}(v)+(1-$ p) $w_{H}=w_{R}(v)+H(1-p)$. Since $w_{H}>w_{R}(v)$, the expected wage if the union selects the strike threat falls as the risk of replacement increases. But since the union selects the strike threat only if the expected strike wage exceeds the holdout wage, this implies that the union becomes less likely to select the strike threat as the risk of replacement increases.

The intuition is as follows. A firm considers the replacement option because it improves the firm's threat payoff relative to the union's, resulting in a lower wage. However, the firm must balance this improvement in the terms of trade with the cost of replacement. A firm only uses replacements if its cost of replacement is sufficiently low. The union, anticipating the possibility of replacement, lowers its wage demand in the strike threat in order to reduce the probability of replacement. This risk of replacement, then, reduces the attractiveness of the strike threat, making it more likely that the union adopts the holdout threat at the outset of negotiations.

With full-information about $v$, settlement occurs immediately. Hence, to be consistent with the data, we need to reintroduce private information about $v$ as well as $k_{f R}$. This need not upset the equilibrium above. The intuition is essentially the same, but now disputes may take time to settle. For a wide range of parameters we get the following equilibrium. The firm surely replaces if its cost of replacement is $L$ and never replaces if its cost of replacement is $H$. In this case replacement signals the cost of replacement, but does not signal anything about $v$. Since replacement is a sunk cost, the signaling of this cost does not play a strategic role. The fraction of strikes involving replacements depends almost entirely on the probability of a low cost of replacement. Empirically, this probability may depend on economic variables such as the local rate of unemployment, or on industry factors such as changes in production technology.

In deciding whether to strike or holdout, the union estimates this probability of replacement. If it is too great, the union selects the holdout threat. Consistent with this model, our econometric strategy is (1) to estimate the risk of replacement based on information available to the union, then (2) to estimate whether an 
increase in replacement risk reduces the union's use of the strike threat, and finally (3) to estimate whether a shift in the composition of disputes away from strikes increases overall dispute activity.

\section{The Firm's Decision to Replace and its Consequences for the Union's Threat Choice}

The summaries given in Tables 1 and 2 suggest that the replacement risk facing a union if it selects the strike threat may vary systematically with some underlying economic factors. Our bargaining model indicates that a union's perceived replacement risk is a key parameter in its choice between the strike and the holdout threat. We assume that unions form their expectations regarding this replacement risk by examining the characteristics of bargaining situations in which replacements were used. Systematic patterns that emerge can be used by a union to inform itself of its own replacement risk.

The firm's decision to replace is based on weighing the wage reductions that can be gained by using replacements versus the cost of hiring replacements. Our model considered a simplified version in which the firm faces either high or low replacement costs. All firms with low replacement costs find it in their interest to replace workers on strike, while all firms with high replacement costs do not find it in their interest to hire replacements.

The union's search for patterns in the replacement data should begin with variables that potentially relate to the firm's cost of using replacements. For example, the more the firm engages in specific training of its workers the more difficult it will be for the firm to find adequately skilled replacements. The decision to hire replacements must also be cast with an eye toward the ability of the firm to quickly find replacement workers. This suggests that conditions in the labor market (local and possibly industry) may be important. Tight labor markets will increase the cost of replacements by driving up the spot wage, or increasing the time required to replace a given fraction of the bargaining unit.

To begin to identify the underlying determinants of the replacement decision, we have collected data on many of the variables relevant to the firm's cost of replacements. Our first effort is to attempt to proxy for differing levels of specific human capital investments across our bargaining units. We do not observe any demographic information on the workers in our bargaining units. Hence, we use only the industry affiliation of the bargaining unit and year of the contract negotiation to construct demographic variables.

We created extracts of union workers using Current Population Survey (CPS) data for the period 19801989. We sorted these workers into major CPS industry/year cells, calculated means of their potential labor market experience, and then smoothed these averages across years using weighted linear regression. We linked these smoothed data series into our collective bargaining file based on the bargaining unit's SIC classification and the expiration year of the prior contract.

Variations in labor market experience will help to capture differences in training investments occurring at the extensive margin. Holding experience constant, differential investment levels across bargaining units 
can arise at the intensive margin due to differences in the rate of job training. We use two different approaches in an attempt to capture this additional source of variation. Industries which on average invest in a higher rate of job training per year should have steeper wage/experience profiles. ${ }^{12}$ To measure these differential returns to experience we created extracts of nonunion workers using CPS surveys for the period 1980-1991. We estimated simple wage equations by major CPS industry. We do not attempt to measure any time variation in these returns to experience, and focus instead on industry differences. ${ }^{13}$

Our second measure is a proxy for differences in technological progress by industry. The variable we use is the industry employment share of scientists and engineers, a measure proposed by Allen (1993). Bartel and Sicherman (1995) find that increases in this employment share are associated with a significant increase in hours of company training among workers in the National Longitudinal Survey of Youth data. They find similar effects when productivity growth or computer investment measures were used in place of the employment share

To study the impact of labor market conditions on the replacement decision, we use measures developed for our earlier studies. Specifically, we measure aggregate labor market conditions using the prime-age male unemployment rate averaged to a quarterly basis. For industry and local labor market conditions we fit regression models to the BLS quarterly unadjusted employment series from 1970 to 1989 allowing for

$$
\begin{gathered}
\ln E_{i t}=\beta_{i 0}+\beta_{i 1} t+\beta_{i 2} t^{2}+\sum_{j=1}^{3} \delta_{i j} Q_{j}+U_{i t} \\
U_{i t}=\phi(L) U_{i t-1}+\varepsilon_{i t},
\end{gathered}
$$

quadratic trends, quarterly seasonal effects, and autoregressive error terms.

where $\ln E_{i t}=\log$ quarterly employment in industry $i$ at time $t ; Q_{j}=$ dummy variable for the $j$ th quarter; $\phi(L)$ $=$ second-order distributed lag polynomial; and $\varepsilon_{i t}=$ white noise error term. We measure the tightness of the labor market using the quarterly employment residual, $\hat{U}_{i t}$, for the quarter in which the prior contract expired. ${ }^{14}$

The structure of collective bargaining in the industry may also have an impact on the firm's replacement decision. The industrial relations literature has long emphasized that the bargaining power of unions depends crucially on the concentration of union membership in an industry. For example, the ability of unions to use

\footnotetext{
${ }^{12} \mathrm{We}$ assume here that firms and workers have an incentive to share in the costs and returns of specific training in order to minimize turnover.

${ }^{13}$ We control for a worker's education, experience, marital status, sex and race. We constructed a similar series of return estimates using the extract of union workers. The process of collective bargaining may introduce several other considerations that affect the wage/experience slopes in union contracts. For this reason, we prefer the nonunion estimates.

${ }^{14}$ Positive residuals correspond to tighter employment conditions.
} 
bargaining tactics such as pattern bargaining is greatly weakened when the union membership becomes fragmented across several unions.

For each industry, a union coverage concentration measure is constructed from the bargaining unit coverage numbers in our data and BLS industry employment data. We observe the size of every bargaining unit at the outset of each contract it negotiates. We interpolate between contracts to construct a bargaining unit coverage history. For each month, we aggregate across bargaining units in a given industry to estimate the total industry coverage. Annual averages of industry coverage levels are normalized by BLS employment rates to arrive at the industry/year coverage rate. ${ }^{15}$ Since the union is identified in our data, we can measure the concentration of the union coverage in an industry across different unions. We calculate by industry and year a Herfindahl index of union coverage concentration.

We consider two additional variables that may affect the firms decision to use replacements. Holding constant the local labor market conditions, the ability of a firm to hire replacements may depend on local union sentiments. If unions enjoy wide public support in a locality, there will be even greater social pressure exerted on workers not to cross picket lines, and on firms not to attempt to hire replacements. To capture geographic variation in this union sentiment, we include an indicator variable which equals one for states that prohibit collective bargaining for their state public sector workers. If public sentiment for unions is lower in these states, then we would expect the risk of replacement to be higher.

The final variable we consider is an indicator for whether "similar" bargaining units experienced replacements in a recent contract negotiation. Unions that observe replacements being used at similar bargaining units may revise upward their assessment of their own replacement risk. We define similar to mean a bargaining unit in the same two-digit industry classification and state. We restrict attention to negotiations that occurred within a year prior to the contract expiration. Specifically, we code an indicator which takes a value of one if a bargaining unit in the same industry and state experienced replacements during contract negotiations that occurred within the prior twelve months of the contract expiration.

Summary statistics on our strike sample disaggregated by the firm's replacement decision are provided in Table 4(a). While our data classify replacements as temporary or permanent, we ignore this distinction for the rest of our analysis. There are several reasons for this decision. The classification of replacements is based on an ex post analysis of the strike. At the time that the firm makes a replacement decision, it is typically unclear if the replacements will be temporary or permanent. Workers that are hired as temporary can be converted to permanent status, while permanent replacements are sometimes dismissed following the end of a strike. ${ }^{16}$ It seems reasonable that the union's primary concern is whether the firm will choose to use replacements.

\footnotetext{
${ }^{15}$ See also Bronars, Deere, and Tracy (1993) for a discussion of constructing firm level unionization measures from this contract data.

${ }^{16}$ The case law provides some restrictions on the process used by the firm to classify replacements as temporary
} 
In order to calculate estimates of replacement risks for bargaining units in our sample, we first estimate a probit model of the firm's replacement decision. Table 5 presents the implied marginal effects of our variables on the probability that the firm uses replacements given that a strike occurs. These marginal effects have been standardized to represent the effect of a one standard deviation change in a continuous variable on the replacement risk, and a unit change in an indicator variable. Our baseline model is given in specification (1). Increasing years of work experience significantly lowers the risk of replacement. A one standard deviation increase in average experience ( 2.2 years), reduces replacement risk by 8 percentage points, nearly 70 percent of the sample standard deviation in the replacement indicator.

To check whether the risk of replacement increased following the replacement of the PATCO strikers, we code an indicator variable which takes a value of one for any negotiation where the prior contract expiration date was after the third quarter of 1981 . We have only a limited number of disputes in our sample that occurred prior to the replacement of the PATCO strikers. However, the data indicate that the risk of replacement increased by over nine percentage points in the post PATCO period, a statistically significant effect.

The other findings are generally consistent with predictions but are imprecisely measured. The risk of replacement is lower when local labor markets are tighter. A one standard deviation increase in the state employment residual is associated with a 2 percentage point reduction in replacement risk. The effect of tightness in the industry labor market is in the same direction, but is much smaller in magnitude. Bargaining units in industries with more concentrated union coverage face lower replacement risk. Bargaining units in states which prohibit collective bargaining by their state public sector workers face a 3 percentage point higher replacement risk. Finally, bargaining units observing prior replacement usage face over a 8 percentage point increase in their replacement risk.

In specification (2), we allow the effect of experience to vary with the nonunion returns to experience. The data indicate that an additional year of experience lowers the risk of replacement differentially more in industries with higher rates of return to experience. Similarly, in specification (3), we allow the effect of experience to vary with the employment share of scientists and engineers. Again, the data indicate that an additional year of experience reduces replacement risk differentially more in industries in which technological progress is likely to be more prevalent. However, the evidence on the importance of the intensive margin is weak given the lack of statistical significance of both of these interactions.

Using specification (1) from Table 5, we predict the probability of replacement for all labor disputes in our sample for which the underlying variables are available. A kernel density estimate of the distribution of the overall replacement risk is presented in Figure 2. Summary statistics on this distribution are provided in Table 6. Consistent with the earlier summary tables, the predicted replacement risk varies widely over bargaining units in our sample. At the extremes, some bargaining units face virtually no risk of replacement,

or permanent. Permanent replacements who are later dismissed, may also have grounds for suing for damages, see Belknap v. Hale, 463 U.S. 491 (1983). 
while others face a risk exceeding 50 percent. We next use this variation in an attempt to measure the impact of replacement risk on the union's observed threat choice.

If increasing the risk of replacement causes unions to shift from the strike to the holdout threat, we would expect to see a negative coefficient on the predicted replacement risk in a threat-choice model. To analyze this, we estimate a probit model of the probability that the union selects the strike threat given that a labor dispute occurs. Table 4(b) provides summary statistics for this sample. Table 7 presents the standardized marginal effects based on the probit coefficients.

Before discussing these results, we would like to address the issue of identification in this sequential probit setup. The model is identified and its parameters consistently estimated if in addition to the standard univariate assumptions on the residuals the following two conditions are satisfied. First, there exists at least one variable which independently shifts the risk of replacement. Second, the errors in the two probits are not correlated due to common left-out variables. If the errors are correlated, then the model suffers from selection bias. To check for this problem, we use a linear probability model for the firm's replacement decision and a probit model for the union's threat choice. This reformulation allows us to use standard methods to test for selection bias. A mills ratio was calculated using the coefficients from the reduced form of the union's threat choice probit model. The coefficient (standard error) on the mills ratio in the firm's replacement decision is $0.032(0.22)$. The data fail to reject the assumption of no selection bias.

Specification (1) of Table 7 estimates a baseline model using disputes from 1980 to 1989. This specification is based on our previous work (Cramton and Tracy 1994). Controlling for economic variables affecting the union's threat choice, the fraction of disputes involving a strike is 10 percentage points lower in the post PATCO period. Specification (2) incorporates the estimated replacement risk displayed in Figure 2. A one standard deviation increase in the estimated replacement risk (11.2 percentage points), leads to a five percentage point decline in the probability that the union selects the strike threat. This confirms the shift in the composition of disputes predicted by the theory. ${ }^{17}$ Controlling for the risk of replacement also reduces the post PATCO marginal effect by 30 percent, making it no longer statistically significant. Specification (3) drops the post PATCO indicator which results in a slight increase in the marginal effect of the predicted replacement risk. Readers interested in a discussion of results for the other determinants of the threat choice are referred to our earlier paper (Cramton and Tracy 1994).

Recall that a key prediction of the theory was a negative coefficient on the real wage variable in the dispute composition model. In earlier work we document that this coefficient estimate switches from negative to positive after 1981. If this sign switch is the result of the replacement risk in the 1980s, then we would

\footnotetext{
${ }^{17}$ This marginal effect relative to the sample average fraction of disputes involving a strike is $27 \%$. When we use a 7-day window to define a holdout, the marginal effect (standard error) on the predicted replacement risk increases to 6.9 (2.6) percentage points, which is $30 \%$ of the average fraction of "disputes" involving a strike. When we use a 30-day window to define a holdout, the marginal effect (standard error) is 11.1 (3.6) percentage points, which is $32 \%$ of the average fraction of "disputes" involving a strike.
} 
expect to find a positive interaction between the real wage variable and the predicted replacement risk. Specification (4) adds this interaction to the model, which the data indicate is positive and significant. Controlling for the interaction effect, the marginal effect for the real wage becomes negative and statistically significant. If the risk of replacement increased significantly after 1981 from its levels in the 1970s, then this positive interaction would help to explain the sign reversal in our previous work.

If the fixed costs of associated with the strike threat are higher than those associated with the holdout threat, then a shift in the composition of disputes away from strikes should lead to a higher overall dispute incidence. We test for this effect in the data in Table 8. Descriptive statistics for this sample are given in Table 4(c). Specification (1) provides a benchmark. In specification (2) we include the predicted probability of a strike given a dispute. A one standard deviation increase in the probability of a strike given a dispute (a 6.6 percentage point rise) is associated with nearly a twenty two percentage point decline in the probability of a dispute (where the mean dispute rate is 52\%). Specifications (3) and (4) explore the extent to which this result reflects variations in the risk of replacement if the strike threat is selected. In specification (3) the data indicate that a one standard deviation increase in the risk of replacement is associated with a fourteen percentage point rise in the incidence of disputes. This is consistent with the earlier finding that as the risk of replacement increases, the union shifts away from the strike threat. ${ }^{18}$ In specification (4) we control for both the probability of a strike given a dispute and the probability of replacement given a strike. The data indicate that there is no independent effect of the risk of replacement controlling for the overall probability of a strike. ${ }^{19}$

The results from the dispute composition and the dispute incidence analysis suggest offsetting effects of the risk of replacement on the likelihood of a strike given a negotiation. As the underlying risk of replacement increases, the composition of disputes shifts away from strikes which leads to a lower strike incidence. However, at the same time the increase in the replacement risk increases the overall dispute incidence which leads to a higher strike incidence. The theoretical model predicts that the composition effect should outweigh the incidence effect. That is, the overall impact of a higher risk of replacement should be a lower strike incidence.

Table 9 checks for this effect in the data. Specification (1) provides a benchmark. Specification (2) adds the predicted risk of replacement, while specification (3) checks to see if the findings are robust to the inclusion of year effects. The coefficient on the predicted replacement risk is negative and imprecisely measured in both

\footnotetext{
${ }^{18}$ This marginal effect relative to the sample average dispute incidence is $21 \%$. When we use a 7 -day window to define a holdout, the marginal effect (standard error) on the predicted replacement risk is 13.9 (2.7) percentage points, which is $33 \%$ of the average "dispute" incidence. When we use a 30-day window to define a holdout the marginal effect (standard error) is 9.7 (2.2) percentage points, which is $34 \%$ of the average"dispute" incidence.

${ }^{19}$ Note that table 8 is based on a sample of 471 disputes and not the 765 disputes analyzed earlier in table 7 . The theory suggests that profit uncertainty affects dispute incidence but need not affect dispute composition. Our uncertainty measure is only available for publicly traded firms. Consequently, in an effort to minimize loss of negotiations we only impose that the uncertainty measure is available for the dispute incidence sample.
} 
specifications. While the sign is consistent with the model, we can not reject the hypothesis that the two effects exactly offset each other.

The results from the dispute composition, dispute incidence, and strike incidence models all suggest the possibility that the basic trends in collective bargaining in the 1980s could be explained in part by the simple hypothesis that the underlying risk of replacement increased in the 1980s. What remains is an attempt to measure how much of the change in bargaining outcomes can reasonably be attributed to this hypothesis. While we do not have the data to answer the question of by how much (if any) the risk of replacement increased from the 1970s to the 1980s, out best estimate is based on the coefficient on the post-PATCO indicator variable in the replacement risk model.

The average predicted replacement risk for the sample of bargaining units negotiating contracts in 19821989 is 11.8 percent based on specification (1) of Table 5. Using the coefficient on the post-PATCO indicator variable from this specification we reestimated the predicted replacement risks as if these negotiations all occurred prior to the PATCO decision. The average predicted replacement risk for this sample falls to 3.3 percent.

We use this implied difference in replacements risks facing each bargaining unit in the 1982-1989 sample to simulate the bargaining outcomes if replacement risks remained at their pre-PATCO levels. The average predicted dispute incidence falls from 54.5 percent to 49.2 percent, roughly a five percentage point change. The average predicted fraction of disputes involving a strike increases from 18.2 percent to 22.9 percent, almost a four percentage point change. These two effects account for over half of the unexplained shifts in dispute incidence and dispute composition documented in Cramton and Tracy (1994). Finally, the strike incidence increases from 11.8 percent to 12.6 percent, less that a full percentage point.

In a similar manner, the empirical models can be used to assess the likely implications of a change in labor law which prohibits the use of replacement workers. We focus relatively more attention to the question of how banning replacements would affect strike incidence since the literature has dealt exclusively with this particular bargaining outcome. Using the model given in specification (3) of Table 9, we estimate strike probabilities for each bargaining unit under the counter factual of no replacement risk. Figure 3 presents kernel density estimates of the distribution of strike incidence probabilities with and without the union facing replacement risk. Table 10 provides descriptive statistics for these two distributions. A ban on replacements increases the mean (median) strike incidence by 1.4 percentage points (1.3), slightly over a ten percent increase in strike incidence.

Table 11 provides a more extensive analysis of the simulated impact of a ban on replacements. This table breaks down the simulated impact into its three components: dispute incidence, dispute composition, and strike incidence. In addition, results are tabulated by year. The largest impacts generally occur in the years immediately following the PATCO decision. Overall, the empirical model indicates that eliminating the risk of replacement would have dramatically altered the course of negotiations in the 1980s. Dispute incidence 
would have fallen by 16 percentage points, while the fraction of disputes involving strikes would have increased by nearly five percentage points. The net impact of these two effects is an increase in the strike incidence of 1.4 percentage points. If we restrict out attention to the post-PATCO period, then the predicted increase in strike incidence is 1.7 percentage points, a 14 percent increase. However, given the imprecision in these estimates, we can not make definitive statements as to the magnitude of the net effect of a replacement ban on strike incidence.

This modest rise in the predicted strike incidence implied by a ban on replacements sharply contrasts with estimates of the impact of replacement bans enacted in three Canadian provinces: Quebec in December 1977, and British Columbia and Ontario in December 1993. Cramton, Gunderson, and Tracy (1993) estimate the impact of these replacement bans as well as other labor policies on real wage settlements, strike incidence, and strike durations. This work extends the earlier work by Gunderson, Kervin, and Reid (1986) and Gunderson and Melino (1990). We use information on over 5,000 contracts negotiated between January 1967 and March 1993. The data indicate that banning replacements led to a 16 percentage point increase in the strike incidence (a doubling), a 40 percent (34 percent) increase in strike durations for large (all) strikes, and a 11 percent increase in the real wage. The Canadian replacement bans also prohibit the firm from using transfers or management to maintain production. This is one reason to expect that their effect on strike incidence would be stronger than what we would predict for the U.S. using the methods we develop in this paper.

\section{Conclusion}

The decline in U.S. strike activity in the 1980s represented a shift by unions from the strike threat to the holdout threat. At the same time, overall dispute rates increased. These changes in bargaining outcomes could be a response to a heightened risk of replacements in the 1980s. To address this issue we estimate the determinants of the firm's decision to use replacements conditional on a strike. We find that firms are reluctant to use replacements the greater the level of job experience of their workers and the tighter the conditions are in the local labor market. We use this empirical model to estimate the replacement risk for each labor dispute in our sample. We find that increases in the risk of replacement significantly reduce the likelihood that the union exercises the strike threat. This reduction in the likelihood of a strike given a dispute significantly increases the incidence of disputes. This increase in dispute incidence mitigates the shift in disputes toward strikes yielding only a modest increase in strike incidence.

The current debate on amending the U.S. labor law to overturn or restrict the McKay Radio doctrine should be informed as to the likely efficiency and distributional effects. In this paper, we demonstrate that this legislation will likely have offsetting effects on the overall costs of negotiating labor contracts. The model and 
data indicate that a ban on replacements will shift the composition of disputes from the low cost threat (holdouts) to the higher cost threat (strikes). Importantly, the model and data also indicate that the total volume of disputes will decline which works in the direction of lowering total negotiation costs. Estimating the net effect on negotiation costs requires estimates of the relative difference in negotiation costs between strikes and holdouts.

\section{References}

Admati, Anat R., and Motty Perry. "Strategic Delay in Bargaining." Review of Economic Studies 54 (July 1987): 345-364.

Allen, Steven G. "Technology and the Wage Structure." Working Paper, North Carolina State University, 1993.

Bartel, Ann P., and Nachum Sicherman. "Technological Change and the Skill Acquisition of Young Workers." Working Paper. Columbia University, March, 1995.

Bronars, Stephen, Donald Deere, and Joseph Tracy. "The Effect of Unions on Firm Behavior: An Empirical Analysis Using Firm-Level Data." Industrial Relations 33 (October 1994): 426-451.

Cappelli, Peter. "Concession Bargaining and the National Economy." In Proceedings of the Thirty-Fifth Annual Meeting, 362-71. Madison, WI, Industrial Relations Research Association, 1982.

Cramton, Peter C., and Joseph S. Tracy. "Strikes and Holdouts in Wage Bargaining: Theory and Data." American Economic Review 82 (March 1992): 100-121.

------, and Joseph S. Tracy. "The Determinants of U.S. Labor Disputes." Journal of Labor Economics 12 (April 1994): 180-209.

Cramton, Peter, Morley Gunderson, and Joseph Tracy. "The Effect of Collective Bargaining Legislation on Strikes and Wages." Working Paper, August, 1993.

Farber, Henry S., and Alan B. Krueger. "Union Membership in the United States: The Decline Continues." Working Paper \#306. Industrial Relations Section, Princeton University, August, 1992.

Freedman, Audrey. "A Fundamental Change in Wage Bargaining." Challenge 25 (July-August 1982): 1417.

------. The New Look in Wage Policy and Employee Relations. New York, The Conference Board, Research Report, 1985.

Gramm, Cynthia L., and John F. Schnell. "Some Empirical Effects of Using Permanent Striker Replacements." Contemporary Economic Policy 12 (July 1994): 122-133.

Gramm, Cynthia. "Employers' Decision to Operate During Strikes: Consequences and Policy Implications." In Employee Rights in a Changing Economy: The Issue of Replacement Workers, edited by William Spriggs. Washington, DC, Economic Policy Institute, 1991.

Gunderson, Morley, John Kervin, and Frank Reid. "Logit Estimates of Strike Incidence from Canadian 
Contract Data." Journal of Labor Economics 4 (April 1989): 257-276.

------, and Angelo Melino. "The Effects of Public Policy on Strike Duration." Journal of Labor Economics 8 (1990): 296-316.

Industrial Union Department. The Inside Game: Winning with Workplace Strategies. Washington, DC, AFL-CIO, 1986.

Kennan, John. "Pareto Optimality and the Economics of Strike Duration." Journal of Labor Research 1 (Spring 1980): 77-94.

Mitchell, Daniel. "Recent Union Contract Concessions." In Brookings Papers on Economic Activity, 165204. Washington, DC, Brookings Institution, 1982.

------. "The 1982 Union Wage Concessions: A Turning Point For Collective Bargaining?" California Management Review 25 (Summer 1983): 78-92.

Olson, Craig. "The Use of Strike Replacements in Labor Disputes: Evidence from the 1880s to the 1980s." Working Paper. Industrial Relations Section, Princeton University, 1991.

Reder, Melvin, and George Neumann. "Conflict and Contract: The Case of Strikes." Journal of Political Economy 88 (1980): 867-886.

Schnell, John F., and Cynthia L. Gramm. "The Empirical Relations Between Employers' Striker Replacement Strategies and Strike Duration." Industrial \& Labor Relations Review 47 (January 1994): 189-206.

U.S. General Accounting Office. "Labor-Management Relations: Strikes and the Use of Permanent Strike Replacements in the 1970s and 1980s." Report to Congressional Requestors, GAO/HRD-91-2, January, 1991. 
Table 1: Incidence of Replacements, by Year.

\begin{tabular}{|c|c|c|c|}
\hline Year & $\begin{array}{c}\text { Negotiation } \\
\mathrm{s}\end{array}$ & $\begin{array}{c}\text { Strikes } \\
\text { (Incidence) }\end{array}$ & $\begin{array}{c}\text { Replacements } \\
\text { (Incidence) }\end{array}$ \\
\hline 1980 & 388 & $\begin{array}{c}43 \\
(11.1)\end{array}$ & $\begin{array}{c}1 \\
(2.3)\end{array}$ \\
\hline 1981 & 264 & $\begin{array}{c}30 \\
(11.4)\end{array}$ & $\begin{array}{c}2 \\
(6.7)\end{array}$ \\
\hline 1982 & 320 & $\begin{array}{c}23 \\
(7.2)\end{array}$ & $\begin{array}{c}2 \\
(8.7)\end{array}$ \\
\hline 1983 & 403 & $\begin{array}{c}35 \\
(8.7)\end{array}$ & $\begin{array}{c}7 \\
(21.2)\end{array}$ \\
\hline 1984 & 313 & $\begin{array}{c}38 \\
(12.1)\end{array}$ & $\begin{array}{c}9 \\
(23.7)\end{array}$ \\
\hline 1985 & 301 & $\begin{array}{c}33 \\
(11.0)\end{array}$ & $\begin{array}{c}5 \\
(15.1)\end{array}$ \\
\hline 1986 & 354 & $\begin{array}{c}45 \\
(12.7)\end{array}$ & $\begin{array}{c}6 \\
(13.3)\end{array}$ \\
\hline 1987 & 238 & $\begin{array}{c}20 \\
(8.4)\end{array}$ & $\begin{array}{c}4 \\
(20.0)\end{array}$ \\
\hline 1988 & 264 & $\begin{array}{c}26 \\
(9.8)\end{array}$ & $\begin{array}{c}4 \\
(15.4)\end{array}$ \\
\hline 1989 & 284 & $\begin{array}{c}19 \\
(6.7)\end{array}$ & $\begin{array}{c}4 \\
(14.1)\end{array}$ \\
\hline & 3,129 & $\begin{array}{c}312 \\
(10.0)\end{array}$ & $\begin{array}{c}44 \\
(14.1)\end{array}$ \\
\hline
\end{tabular}


Table 2: Incidence of Replacements, by Industry

\begin{tabular}{|c|c|c|}
\hline CPS Industry & $\begin{array}{l}\text { Number of } \\
\text { Strikes }\end{array}$ & $\begin{array}{l}\text { Number of } \\
\text { Replacement } \\
\text { s }\end{array}$ \\
\hline Primary Metals & 14 & $\begin{array}{c}1 \\
(7.1)\end{array}$ \\
\hline Fabricated Metals & 16 & $\begin{array}{c}0 \\
(0.0)\end{array}$ \\
\hline Machinery, except Electrical & 26 & $\begin{array}{c}1 \\
(3.9)\end{array}$ \\
\hline Electrical Equipment & 14 & $\begin{array}{c}1 \\
(7.2)\end{array}$ \\
\hline Trans Equip - Automobiles & 16 & $\begin{array}{c}0 \\
(0.0)\end{array}$ \\
\hline Trans Equip - Aircraft & 16 & $\begin{array}{c}4 \\
(25.0)\end{array}$ \\
\hline Trans Equip - Other & 14 & $\begin{array}{c}3 \\
(21.4)\end{array}$ \\
\hline Food & 21 & $\begin{array}{c}5 \\
(23.8)\end{array}$ \\
\hline Paper & 15 & $\begin{array}{c}3 \\
(20.0)\end{array}$ \\
\hline Other Trans & 20 & $\begin{array}{c}7 \\
(35.0)\end{array}$ \\
\hline Communications & 16 & $\begin{array}{c}2 \\
(12.5)\end{array}$ \\
\hline Other Public Utilities & 21 & $\begin{array}{c}2 \\
(9.5)\end{array}$ \\
\hline Other Retail Trade & 20 & $\begin{array}{c}9 \\
(45.0)\end{array}$ \\
\hline Medical, except Hospitals & 19 & $\begin{array}{c}6 \\
(31.6)\end{array}$ \\
\hline
\end{tabular}

Notes: Cell counts (row percents) given for industries with at least 10 strikes in the sample period. 
Table 3: Dispute Incidence and Composition with a 1\% Fixed Cost of Striking

\begin{tabular}{ccccccc}
\hline \hline & Strike & Holdout & Dispute & Prob. Strike \\
Incidence & Incidence & Incidence & $\begin{array}{c}\text { Prob. Dispute } \\
\text { Given Strike } \\
\text { Threat }\end{array}$ & $\begin{array}{c}\text { Prob. Dispute } \\
\text { Given } \\
\text { Holdout } \\
\text { Threat }\end{array}$ \\
\hline $\begin{array}{c}\text { No Fixed } \\
\text { Cost }\end{array}$ & 10 & 41 & 52 & 20 & 52 & 52 \\
$\begin{array}{c}1 \% \text { Cost to } \\
\text { Union }\end{array}$ & 4 & 43 & 47 & 16 & 22 & 52 \\
$\begin{array}{c}1 \% \text { Cost } \\
\text { Equally Split } \\
1 \% \text { Cost to }\end{array}$ & 5 & 41 & 45 & 21 & 22 & 52 \\
Firm & 6 & 38 & 44 & 26 & 22 & 52 \\
\hline
\end{tabular}

Notes: Calculations based on benchmark parameters in Cramton and Tracy (1994). No fixed cost assumed for holdout threat. 
Table 4: Descriptive Statistics

\begin{tabular}{|c|c|c|c|c|c|c|}
\hline \multicolumn{7}{|c|}{ (a) Strike Sample, 1980-1989 } \\
\hline \multirow[b]{2}{*}{ Variable } & \multicolumn{2}{|c|}{ Overall } & \multicolumn{2}{|c|}{ No Replacements } & \multicolumn{2}{|c|}{ Replacements } \\
\hline & Mean & Std Dev & Mean & Std Dev & Mean & Std Dev \\
\hline $\begin{array}{l}\text { Replacement } \\
\text { indicator }\end{array}$ & 0.134 & 0.341 & & & & \\
\hline Experience & 22.1 & 2.2 & 22.4 & 2.0 & 20.4 & 2.8 \\
\hline $\begin{array}{l}\text { Nonunion returns to } \\
\text { experience }\end{array}$ & 0.007 & 0.002 & 0.007 & 0.002 & 0.006 & 0.002 \\
\hline $\begin{array}{l}\text { Scientist \& engineer } \\
\text { employment share }\end{array}$ & 0.050 & 0.037 & 0.052 & 0.036 & 0.034 & 0.039 \\
\hline $\begin{array}{l}\text { State employment } \\
\text { residual }\end{array}$ & -0.007 & 0.035 & -0.005 & 0.036 & -0.017 & 0.028 \\
\hline $\begin{array}{l}\text { Industry employment } \\
\text { residual }\end{array}$ & -0.011 & 0.077 & -0.009 & 0.080 & -0.023 & 0.054 \\
\hline $\begin{array}{l}\text { Union coverage } \\
\text { concentration }\end{array}$ & 0.565 & 0.246 & 0.566 & 0.244 & 0.556 & 0.257 \\
\hline $\begin{array}{l}\text { Prior replacement } \\
\text { useage }\end{array}$ & 0.020 & 0.139 & 0.018 & 0.134 & 0.029 & 0.171 \\
\hline $\begin{array}{l}\text { Collective bargaining } \\
\text { prohibited for state } \\
\text { workers }\end{array}$ & 0.098 & 0.298 & 0.100 & 0.301 & 0.088 & 0.288 \\
\hline Post PATCO indicator & 0.787 & 0.410 & 0.764 & 0.426 & 0.941 & 0.239 \\
\hline Sample size & \multicolumn{2}{|c|}{254} & \multicolumn{2}{|c|}{220} & \multicolumn{2}{|c|}{34} \\
\hline
\end{tabular}


Table 4: Descriptive Statistics, Continued

\begin{tabular}{|c|c|c|c|c|c|c|}
\hline \multicolumn{7}{|c|}{ (b) Dispute Sample, 1980-1989 } \\
\hline \multirow[b]{2}{*}{ Variable } & \multicolumn{2}{|c|}{ Overall } & \multicolumn{2}{|c|}{ No Strike } & \multicolumn{2}{|c|}{ Strike } \\
\hline & Mean & Std Dev & Mean & Std Dev & Mean & Std Dev \\
\hline Strike Indicator & 0.187 & 0.390 & & & & \\
\hline Unemployment rate & 6.05 & 1.42 & 6.06 & 1.43 & 5.99 & 1.41 \\
\hline $\begin{array}{l}\text { State employment } \\
\text { residual }\end{array}$ & -0.008 & 0.036 & -0.008 & 0.036 & -0.010 & 0.035 \\
\hline $\begin{array}{l}\text { State employment } \\
\text { trend }\end{array}$ & 0.005 & 0.002 & 0.005 & 0.002 & 0.005 & 0.002 \\
\hline $\begin{array}{l}\text { Industry employment } \\
\text { residual }\end{array}$ & -0.009 & 0.074 & -0.009 & 0.070 & -0.007 & 0.086 \\
\hline $\begin{array}{l}\text { Industry employment } \\
\text { trend }\end{array}$ & -0.001 & 0.005 & -0.001 & 0.006 & -0.001 & 0.004 \\
\hline $\begin{array}{l}\text { Union coverage } \\
\text { density }\end{array}$ & 0.232 & 0.211 & 0.225 & 0.201 & 0.263 & 0.248 \\
\hline $\begin{array}{l}\text { Union coverage } \\
\text { concentration }\end{array}$ & 0.594 & 0.234 & 0.602 & 0.231 & 0.562 & 0.246 \\
\hline $\begin{array}{l}\% \text { change in real wage } \\
\text { over prior contract }\end{array}$ & -0.033 & 0.077 & -0.032 & 0.077 & -0.036 & 0.079 \\
\hline Post PATCO indicator & 0.817 & 0.387 & 0.829 & 0.376 & 0.762 & 0.427 \\
\hline $\begin{array}{l}\text { Predicted replacement } \\
\text { risk }\end{array}$ & 0.111 & 0.112 & 0.114 & 0.117 & 0.097 & 0.089 \\
\hline Sample size & & & & & & \\
\hline
\end{tabular}


Table 4: Descriptive Statistics, Continued

\begin{tabular}{|c|c|c|c|c|c|c|}
\hline \multicolumn{7}{|c|}{ (c) Negotiation Sample, 1980-1989 } \\
\hline \multirow[b]{2}{*}{ Variable } & \multicolumn{2}{|c|}{ Overall } & \multicolumn{2}{|c|}{ No Dispute } & \multicolumn{2}{|c|}{ Dispute } \\
\hline & Mean & Std Dev & Mean & Std Dev & Mean & Std Dev \\
\hline Dispute Indicator & 0.520 & 0.500 & & & & \\
\hline Strike Indicator & 0.112 & 0.315 & & & & \\
\hline Unemployment rate & 6.05 & 1.43 & 6.04 & 1.45 & 6.06 & 1.41 \\
\hline $\begin{array}{l}\text { State employment } \\
\text { residual }\end{array}$ & -0.007 & 0.039 & -0.008 & 0.039 & -0.007 & 0.038 \\
\hline $\begin{array}{l}\text { State employment } \\
\text { trend }\end{array}$ & 0.005 & 0.002 & 0.005 & 0.002 & 0.005 & 0.002 \\
\hline $\begin{array}{l}\text { Industry employment } \\
\text { residual }\end{array}$ & -0.002 & 0.079 & 0.003 & 0.077 & -0.007 & 0.081 \\
\hline $\begin{array}{l}\text { Industry employment } \\
\text { trend }\end{array}$ & -0.001 & 0.005 & -0.001 & 0.005 & -0.001 & 0.005 \\
\hline $\begin{array}{l}\text { Union coverage } \\
\text { density }\end{array}$ & 0.274 & 0.214 & 0.274 & 0.218 & 0.274 & 0.211 \\
\hline $\begin{array}{l}\text { Union coverage } \\
\text { concentration }\end{array}$ & 0.566 & 0.238 & 0.554 & 0.247 & 0.576 & 0.229 \\
\hline $\begin{array}{l}\% \text { change in real wage } \\
\text { over prior contract }\end{array}$ & -0.044 & 0.072 & -0.052 & 0.076 & -0.036 & 0.067 \\
\hline $\begin{array}{l}\text { Standard deviation of } \\
\text { firm's excess returns }\end{array}$ & 0.017 & 0.006 & 0.017 & 0.007 & 0.017 & 0.006 \\
\hline $\begin{array}{l}\text { Predicted strike } \\
\text { risk }\end{array}$ & 0.209 & 0.066 & 0.221 & 0.068 & 0.198 & 0.062 \\
\hline $\begin{array}{l}\text { Predicted replacement } \\
\text { risk }\end{array}$ & 0.094 & 0.087 & 0.082 & 0.068 & 0.105 & 0.101 \\
\hline Sample size & & 5 & & & & \\
\hline
\end{tabular}


Table 5: Probit Model of Replacement Risk

\begin{tabular}{lccc}
\hline \hline Variable & $(1)$ & $(2)$ & $(3)$ \\
\hline Experience & -0.079 & -0.072 & -0.069 \\
& $(0.017)$ & $(0.020)$ & $(0.020)$ \\
Experience x nonunion & & -0.012 & \\
returns to experience & & $(0.020)$ & \\
Experience x scientist \& engineer & & & -0.018 \\
employment share & & & $(0.022)$ \\
State employment residual & -0.021 & -0.020 & -0.022 \\
& $(0.024)$ & $(0.024)$ & $(0.024)$ \\
Industry employment residual & -0.011 & -0.010 & -0.008 \\
& $(0.023)$ & $(0.023)$ & $(0.024)$ \\
Union coverage concentration & -0.022 & -0.023 & -0.022 \\
& $(0.019)$ & $(0.019)$ & $(0.019)$ \\
Prior replacement useage & 0.086 & 0.106 & 0.110 \\
& $(0.165)$ & $(0.179)$ & $(0.180)$ \\
Collective bargaining & 0.030 & 0.028 & 0.031 \\
prohibited for state workers & $(0.077)$ & $(0.076)$ & $(0.077)$ \\
Post PATCO indicator & 0.094 & 0.096 & 0.095 \\
& $(0.039)$ & $(0.038)$ & $(0.038)$ \\
Log likelihood & -84.60 & -84.24 & -84.27 \\
Number of observations & 254 & 254 & 254 \\
\hline Notes: Coefficients represent the & & &
\end{tabular}

Notes: Coefficients represent the marginal effect of a one standard deviation change in a continuous variable, or a unit change in an indicator variable on the replacement probability. Standard errors are given in parentheses. 
Table 6: Summary Statistics on Predicted Replacement Risk

\begin{tabular}{ccccccccc}
\hline \hline Minimum & $10 \%$ & $25 \%$ & $50 \%$ & $75 \%$ & $90 \%$ & Maximum & Mean & Std Dev \\
\hline 0.001 & 0.015 & 0.039 & 0.079 & 0.136 & 0.248 & 0.726 & 0.111 & 0.112 \\
\hline
\end{tabular}

Notes: Based on specification (1) of Table 5. 
Table 7: Probit Model of the Probability of a Strike Given a Dispute

\begin{tabular}{|c|c|c|c|c|c|}
\hline Variable & (1) & (2) & (3) & (4) & (5) \\
\hline Unemployment rate & $\begin{array}{l}-0.023 \\
(0.019)\end{array}$ & $\begin{array}{l}-0.015 \\
(0.019)\end{array}$ & $\begin{array}{l}-0.015 \\
(0.019)\end{array}$ & $\begin{array}{l}-0.011 \\
(0.019)\end{array}$ & $\begin{array}{l}-0.008 \\
(0.049)\end{array}$ \\
\hline State employment residual & $\begin{array}{l}-0.041 \\
(0.021)\end{array}$ & $\begin{array}{l}-0.054 \\
(0.021)\end{array}$ & $\begin{array}{l}-0.046 \\
(0.020)\end{array}$ & $\begin{array}{l}-0.050 \\
(0.022)\end{array}$ & $\begin{array}{l}-0.058 \\
(0.021)\end{array}$ \\
\hline State employment trend & $\begin{array}{l}-0.007 \\
(0.015)\end{array}$ & $\begin{array}{l}-0.007 \\
(0.015)\end{array}$ & $\begin{array}{l}-0.008 \\
(0.015)\end{array}$ & $\begin{array}{l}-0.010 \\
(0.015)\end{array}$ & $\begin{array}{l}-0.008 \\
(0.015)\end{array}$ \\
\hline $\begin{array}{l}\text { Industry employment } \\
\text { residual }\end{array}$ & $\begin{array}{c}0.004 \\
(0.015)\end{array}$ & $\begin{array}{c}0.002 \\
(0.015)\end{array}$ & $\begin{array}{c}0.003 \\
(0.015)\end{array}$ & $\begin{array}{c}0.020 \\
(0.015)\end{array}$ & $\begin{array}{c}0.004 \\
(0.015)\end{array}$ \\
\hline Industry employment trend & $\begin{array}{l}-0.012 \\
(0.015)\end{array}$ & $\begin{array}{c}0.003 \\
(0.017)\end{array}$ & $\begin{array}{c}0.007 \\
(0.017)\end{array}$ & $\begin{array}{c}0.009 \\
(0.016)\end{array}$ & $\begin{array}{c}0.002 \\
(0.017)\end{array}$ \\
\hline Union coverage density & $\begin{array}{c}0.034 \\
(0.014)\end{array}$ & $\begin{array}{c}0.038 \\
(0.014)\end{array}$ & $\begin{array}{c}0.040 \\
(0.014)\end{array}$ & $\begin{array}{c}0.042 \\
(0.014)\end{array}$ & $\begin{array}{c}0.038 \\
(0.015)\end{array}$ \\
\hline $\begin{array}{l}\text { Union coverage } \\
\text { concentration }\end{array}$ & $\begin{array}{l}-0.036 \\
(0.015)\end{array}$ & $\begin{array}{l}-0.046 \\
(0.016)\end{array}$ & $\begin{array}{l}-0.050 \\
(0.016)\end{array}$ & $\begin{array}{l}-0.047 \\
(0.015)\end{array}$ & $\begin{array}{l}-0.047 \\
(0.016)\end{array}$ \\
\hline $\begin{array}{l}\% \text { change in real wage over } \\
\text { prior contract }\end{array}$ & $\begin{array}{c}0.010 \\
(0.017)\end{array}$ & $\begin{array}{c}0.007 \\
(0.017)\end{array}$ & $\begin{array}{l}-0.003 \\
(0.015)\end{array}$ & $\begin{array}{l}-0.041 \\
(0.019)\end{array}$ & $\begin{array}{l}-0.000 \\
(0.019)\end{array}$ \\
\hline $\begin{array}{l}\% \text { change in real wage over } \\
\text { prior contract } x \text { predicted } \\
\text { replacement risk }\end{array}$ & & & & $\begin{array}{c}0.066 \\
(0.022)\end{array}$ & \\
\hline Post PATCO indicator & $\begin{array}{l}-0.104 \\
(0.057)\end{array}$ & $\begin{array}{l}-0.070 \\
(0.056)\end{array}$ & & & \\
\hline Predicted replacement risk & & $\begin{array}{l}-0.050 \\
(0.022)\end{array}$ & $\begin{array}{l}-0.058 \\
(0.024)\end{array}$ & $\begin{array}{l}-0.049 \\
(0.020)\end{array}$ & $\begin{array}{l}-0.051 \\
(0.024)\end{array}$ \\
\hline Year effects included & No & No & No & No & $Y \mathrm{es}^{\mathrm{a}}$ \\
\hline Log likelihood & -359.40 & -356.68 & -357.56 & -353.26 & -354.78 \\
\hline Number of observations & 765 & 765 & 765 & 765 & 765 \\
\hline
\end{tabular}

Notes: Predicted replacement probabilities based on specification (1) of Table 5. Coefficients represent the marginal effect of a one standard deviation change in a continuous variable (a unit change for an indicator variable) on the strike probability. Standard errors are given in parentheses, and for specification (2)-(4) have been adjusted for the two step estimation procedure used.

${ }^{a} \chi^{2}$ test statistic (probability value) for year effects $=5.45(0.79)$. 
Table 8: Probit Model of the Probability of a Labor Dispute

\begin{tabular}{|c|c|c|c|c|c|}
\hline Variable & (1) & (2) & (3) & (4) & (5) \\
\hline Unemployment rate & $\begin{array}{c}0.001 \\
(0.021)\end{array}$ & $\begin{array}{l}-0.075 \\
(0.025)\end{array}$ & $\begin{array}{l}-0.030 \\
(0.021)\end{array}$ & $\begin{array}{l}-0.090 \\
(0.030)\end{array}$ & $\begin{array}{l}-0.083 \\
(0.053)\end{array}$ \\
\hline State employment residual & $\begin{array}{c}0.025 \\
(0.022)\end{array}$ & $\begin{array}{l}-0.074 \\
(0.021)\end{array}$ & $\begin{array}{c}0.076 \\
(0.024)\end{array}$ & $\begin{array}{l}-0.131 \\
(0.070)\end{array}$ & $\begin{array}{l}-0.040 \\
(0.032)\end{array}$ \\
\hline State employment trend & $\begin{array}{c}0.030 \\
(0.018)\end{array}$ & $\begin{array}{l}-0.003 \\
(0.019)\end{array}$ & $\begin{array}{c}0.028 \\
(0.018)\end{array}$ & $\begin{array}{l}-0.015 \\
(0.023)\end{array}$ & $\begin{array}{l}-0.006 \\
(0.019)\end{array}$ \\
\hline $\begin{array}{l}\text { Industry employment } \\
\text { residual }\end{array}$ & $\begin{array}{l}-0.037 \\
(0.019)\end{array}$ & $\begin{array}{l}-0.015 \\
(0.020)\end{array}$ & $\begin{array}{l}-0.026 \\
(0.019)\end{array}$ & $\begin{array}{l}-0.012 \\
(0.020)\end{array}$ & $\begin{array}{c}0.006 \\
(0.020)\end{array}$ \\
\hline Industry employment trend & $\begin{array}{c}0.022 \\
(0.018)\end{array}$ & $\begin{array}{c}0.010 \\
(0.018)\end{array}$ & $\begin{array}{l}-0.008 \\
(0.019)\end{array}$ & $\begin{array}{c}0.018 \\
(0.021)\end{array}$ & $\begin{array}{c}0.015 \\
(0.018)\end{array}$ \\
\hline Union coverage density & $\begin{array}{l}-0.001 \\
(0.018)\end{array}$ & $\begin{array}{c}0.124 \\
(0.028)\end{array}$ & $\begin{array}{l}-0.014 \\
(0.018)\end{array}$ & $\begin{array}{c}0.174 \\
(0.064)\end{array}$ & $\begin{array}{c}0.131 \\
(0.029)\end{array}$ \\
\hline $\begin{array}{l}\text { Union coverage } \\
\text { concentration }\end{array}$ & $\begin{array}{c}0.012 \\
(0.018)\end{array}$ & $\begin{array}{l}-0.126 \\
(0.029)\end{array}$ & $\begin{array}{c}0.040 \\
(0.019)\end{array}$ & $\begin{array}{l}-0.188 \\
(0.078)\end{array}$ & $\begin{array}{l}-0.128 \\
(0.030)\end{array}$ \\
\hline $\begin{array}{l}\% \text { change in real wage over } \\
\text { prior contract }\end{array}$ & $\begin{array}{c}0.057 \\
(0.018)\end{array}$ & $\begin{array}{c}0.033 \\
(0.017)\end{array}$ & $\begin{array}{c}0.047 \\
(0.018)\end{array}$ & $\begin{array}{c}0.029 \\
(0.018)\end{array}$ & $\begin{array}{c}0.005 \\
(0.023)\end{array}$ \\
\hline $\begin{array}{l}\text { Standard deviation of } \\
\text { firm's excess returns }\end{array}$ & $\begin{array}{l}-0.012 \\
(0.017)\end{array}$ & $\begin{array}{c}0.008 \\
(0.017)\end{array}$ & $\begin{array}{c}0.005 \\
(0.018)\end{array}$ & $\begin{array}{c}0.008 \\
(0.017)\end{array}$ & $\begin{array}{c}0.013 \\
(0.019)\end{array}$ \\
\hline Predicted strike risk & & $\begin{array}{l}-0.219 \\
(0.033)\end{array}$ & & $\begin{array}{l}-0.297 \\
(0.097)\end{array}$ & $\begin{array}{l}-0.203 \\
(0.039)\end{array}$ \\
\hline Predicted replacement risk & & & $\begin{array}{c}0.140 \\
(0.027)\end{array}$ & $\begin{array}{l}-0.058 \\
(0.068)\end{array}$ & \\
\hline Year effects included & No & No & No & No & Yes $^{\mathrm{a}}$ \\
\hline Log likelihood & -615.53 & -595.68 & -599.71 & -595.32 & -582.44 \\
\hline Number of observations & 905 & 905 & 905 & 905 & 905 \\
\hline
\end{tabular}

Notes: Predicted replacement probabilities based on specification (1) of Table 5. Predicted strike probabilities based on specification (3) of Table 7. Coefficients represent the marginal effect of a one standard deviation change in a continuous variable (a unit change for an indicator variable) on the dispute probability. Standard errors are given in parentheses, and for specification (2)-(5) have been adjusted for the multi-step estimation procedure used.

$\chi^{2}$ test statistic (probability value) for year effects $=29.6(0.0005)$. 
Table 9: Probit Model of the Probability of a Strike Given a Negotiation

\begin{tabular}{|c|c|c|c|}
\hline Variable & (1) & (2) & (3) \\
\hline Unemployment rate & $\begin{array}{l}-0.015 \\
(0.013)\end{array}$ & $\begin{array}{l}-0.013 \\
(0.014)\end{array}$ & $\begin{array}{l}-0.032 \\
(0.032)\end{array}$ \\
\hline State employment residual & $\begin{array}{c}0.006 \\
(0.014)\end{array}$ & $\begin{array}{c}0.004 \\
(0.015)\end{array}$ & $\begin{array}{c}0.005 \\
(0.015)\end{array}$ \\
\hline State employment trend & $\begin{array}{l}-0.016 \\
(0.011)\end{array}$ & $\begin{array}{l}-0.016 \\
(0.011)\end{array}$ & $\begin{array}{l}-0.017 \\
(0.012)\end{array}$ \\
\hline Industry employment residual & $\begin{array}{l}-0.011 \\
(0.011)\end{array}$ & $\begin{array}{l}-0.012 \\
(0.011)\end{array}$ & $\begin{array}{l}-0.009 \\
(0.012)\end{array}$ \\
\hline Industry employment trend & $\begin{array}{c}0.004 \\
(0.011)\end{array}$ & $\begin{array}{c}0.006 \\
(0.011)\end{array}$ & $\begin{array}{c}0.007 \\
(0.012)\end{array}$ \\
\hline Union coverage density & $\begin{array}{c}0.013 \\
(0.011)\end{array}$ & $\begin{array}{c}0.013 \\
(0.011)\end{array}$ & $\begin{array}{c}0.015 \\
(0.011)\end{array}$ \\
\hline Union coverage concentration & $\begin{array}{l}-0.001 \\
(0.011)\end{array}$ & $\begin{array}{l}-0.011 \\
(0.012)\end{array}$ & $\begin{array}{l}-0.014 \\
(0.012)\end{array}$ \\
\hline $\begin{array}{l}\% \text { change in real wage over prior } \\
\text { contract }\end{array}$ & $\begin{array}{c}0.034 \\
(0.011)\end{array}$ & $\begin{array}{c}0.035 \\
(0.011)\end{array}$ & $\begin{array}{c}0.030 \\
(0.014)\end{array}$ \\
\hline $\begin{array}{l}\text { Standard deviation of } \\
\text { firm's excess returns }\end{array}$ & $\begin{array}{c}0.004 \\
(0.010)\end{array}$ & $\begin{array}{l}0.003 \\
(0.011\end{array}$ & $\begin{array}{c}0.004 \\
(0.011)\end{array}$ \\
\hline Predicted replacement risk & & $\begin{array}{l}-0.007 \\
(0.015)\end{array}$ & $\begin{array}{l}-0.012 \\
(0.016)\end{array}$ \\
\hline Year Effects Included & No & No & Yes \\
\hline Log likelihood & -309.22 & -309.09 & -307.52 \\
\hline Number of observations & 905 & 905 & 905 \\
\hline
\end{tabular}

Notes: Predicted replacement probabilities based on specification (1) of Table 5. Coefficients represent the marginal effect of a one standard deviation change in a continuous variable (a unit change for an indicator variable) on the dispute probability. Standard errors are given in parentheses, and for specification (2) and (3) have been adjusted for the multi-step estimation procedure used. 
Table 10: Simulated Ban on Replacement Workers, Overall

\begin{tabular}{rcccccccccc}
\hline \hline Strike Incidence & Minimum & $10 \%$ & $25 \%$ & $50 \%$ & $75 \%$ & $90 \%$ & $\begin{array}{c}\text { Maximu } \\
\mathrm{m}\end{array}$ & Mean & Std Dev \\
\hline With Replacements & 0.020 & 0.058 & 0.078 & 0.107 & 0.139 & 0.172 & 0.271 & 0.111 & 0.045 \\
No Replacements & 0.020 & 0.066 & 0.088 & 0.120 & 0.158 & 0.190 & 0.323 & 0.125 & 0.049 \\
\hline
\end{tabular}

Notes: Based on specification (3) of Table 9. 
Table 11: Simulated Impact of a Ban on Replacement Workers, By Year

\begin{tabular}{|c|c|c|c|c|c|c|}
\hline \multirow[b]{2}{*}{ Year } & \multicolumn{3}{|c|}{ Predicted Dispute Incidence } & \multicolumn{3}{|c|}{$\begin{array}{l}\text { Predicted Strike Incidence } \\
\text { Given a Labor Dispute }\end{array}$} \\
\hline & $\begin{array}{c}\text { Repl. } \\
\text { Allowe } \\
\text { d }\end{array}$ & $\begin{array}{l}\text { Repl. } \\
\text { Prohibited }\end{array}$ & $\begin{array}{l}\text { Percentage } \\
\text { Point } \\
\text { Change }\end{array}$ & $\begin{array}{c}\text { Repl. } \\
\text { Allowe } \\
\text { d }\end{array}$ & $\begin{array}{c}\text { Repl. } \\
\text { Prohibite } \\
\text { d }\end{array}$ & $\begin{array}{l}\text { Percentage } \\
\text { Point Change }\end{array}$ \\
\hline 1980 & 35.2 & 37.9 & 2.7 & 29.9 & 31.8 & 1.9 \\
\hline 1981 & 48.0 & 36.0 & -12.0 & 20.4 & 22.4 & 2.0 \\
\hline 1982 & 51.6 & 25.6 & -26.0 & 18.5 & 27.4 & 8.9 \\
\hline 1983 & 54.8 & 26.0 & -28.8 & 19.1 & 27.8 & 8.7 \\
\hline 1984 & 50.6 & 38.0 & -12.6 & 22.8 & 29.3 & 6.5 \\
\hline 1985 & 60.0 & 41.4 & -18.6 & 19.9 & 24.7 & 4.8 \\
\hline 1986 & 73.0 & 42.1 & -30.9 & 21.2 & 25.3 & 4.1 \\
\hline 1987 & 57.3 & 42.3 & -15.0 & 13.2 & 16.8 & 3.6 \\
\hline 1988 & 55.8 & 47.0 & -8.8 & 19.1 & 22.7 & 3.6 \\
\hline 1989 & 52.8 & 40.6 & -12.2 & 16.7 & 19.9 & 3.2 \\
\hline $1980-1989$ & $\begin{array}{c}52.1 \\
(1.6)^{\mathrm{a}}\end{array}$ & $\begin{array}{l}36.1 \\
(4.4)\end{array}$ & $\begin{array}{l}-16.0 \\
(4.1)\end{array}$ & $\begin{array}{l}21.4 \\
(1.6)\end{array}$ & $\begin{array}{l}26.3 \\
(3.9)\end{array}$ & $\begin{array}{l}4.9 \\
(3.3)\end{array}$ \\
\hline 1982 - 1989 & $\begin{array}{l}57.0 \\
(1.9)\end{array}$ & $\begin{array}{l}35.7 \\
(5.3)\end{array}$ & $\begin{array}{l}-21.3 \\
(5.0)\end{array}$ & $\begin{array}{l}19.3 \\
(1.7)\end{array}$ & $\begin{array}{l}25.4 \\
(4.5)\end{array}$ & $\begin{array}{l}6.1 \\
(3.9)\end{array}$ \\
\hline
\end{tabular}

Notes: Predicted dispute incidence is based on specification (5) of Table 8. Predicted strike incidence given a dispute is based on specification (5) of Table 7. Predicted strike incidence given a negotiation is based on specification (3) of Table 9. Standard errors are given in parentheses.

aStandard errors are based on 5,000 simulations. 
Table 11: Continued

\begin{tabular}{ccccc}
\hline & \multicolumn{4}{c}{$\begin{array}{c}\text { Predicted Strike Incidence } \\
\text { Given a Negotiation }\end{array}$} \\
\cline { 2 - 5 } Year & $\begin{array}{c}\text { Repl. } \\
\text { Allowed }\end{array}$ & $\begin{array}{c}\text { Repl. } \\
\text { Prohibited }\end{array}$ & $\begin{array}{c}\text { Percentage } \\
\text { Point } \\
\text { Change }\end{array}$ & $\begin{array}{c}\text { Percent } \\
\text { Change }\end{array}$ \\
\hline 1980 & 9.1 & 9.4 & 0.3 & 3.3 \\
1981 & 8.0 & 8.4 & 0.4 & 5.0 \\
1982 & 8.8 & 11.0 & 2.2 & 25.0 \\
1983 & 10.3 & 12.7 & 2.4 & 23.3 \\
1984 & 12.6 & 14.4 & 1.8 & 14.3 \\
1985 & 16.7 & 18.5 & 1.8 & 10.8 \\
1986 & 15.8 & 17.2 & 1.4 & 8.9 \\
1987 & 9.3 & 10.4 & 1.1 & 11.8 \\
1988 & 13.5 & 14.7 & 1.2 & 8.9 \\
1989 & 11.5 & 12.4 & 0.9 & 7.8 \\
\hline $1980-1989$ & 11.1 & 12.5 & 1.4 & 12.6 \\
& $(1.0)$ & $(2.8)$ & $(2.5)$ & \\
$1982-1989$ & 12.1 & 13.8 & 1.7 & 14.1 \\
& $(1.3)$ & $(3.4)$ & $(3.1)$ & \\
\hline
\end{tabular}

Notes: Predicted dispute incidence is based on specification (5) of Table 8. Predicted strike incidence given a dispute is based on specification (5) of Table 7. Predicted strike incidence given a negotiation is based on specification (3) of Table 9. Standard errors are given in parentheses.

aStandard errors are based on 5,000 simulations. 


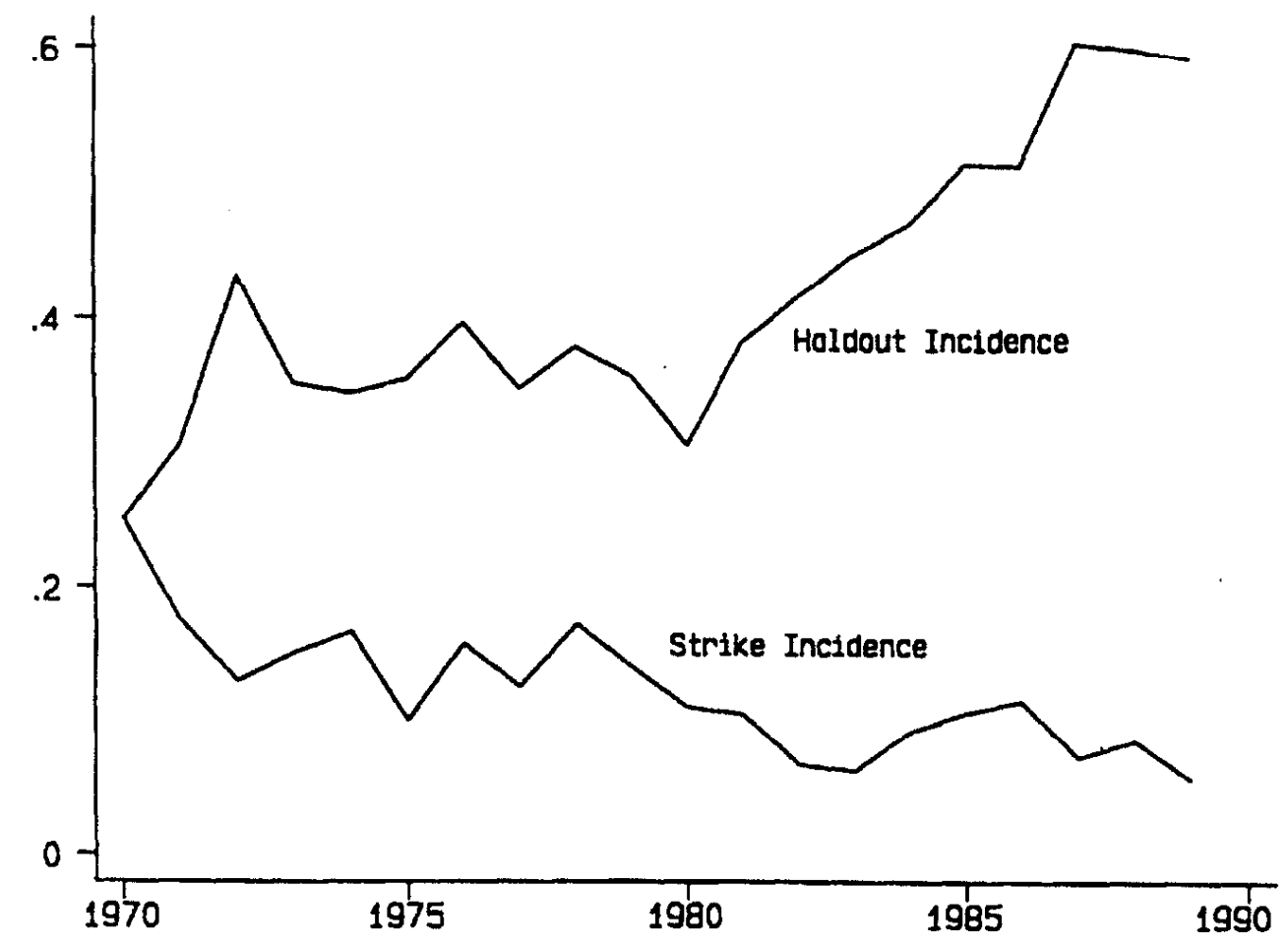

Notes: Based on Bureau of Labor Statistics data on 7,196 negotiations involving bargaining units greater than 1,000 workers in size. Exlcudes scheduled reopenings of contracts and bargaining units covered by the Railway Labor Act.

Figure 1 